九州大学学術情報リポジトリ

Kyushu University Institutional Repository

\title{
Analysis on Policies and Agricultural Transition : Challenges in Promoting Sustainable Agriculture in Northern Laos
}

\section{Southavilay, Boundeth}

Laboratory of Agricultural and Farm Management, Department of Agricultural and Resources

Economics, Graduate school of Bioresource and Bioenvironmental Science, Kyushu University

\section{Nanseki, Teruaki}

Laboratory of Agricultural and Farm Management, Division of International Agricultural Resource Economics and Business Administration, Department of Agricultural and Resource Economics, Faculty of Agriculture, Kyushu University

Takeuchi, Shigeyoshi

Laboratory of Agricultural and Farm Management, Division of International Agricultural Resource Economics and Business Administration, Department of Agricultural and Resource Economics, Faculty of Agriculture, Kyushu University

https://doi.org/10.5109/26183

出版情報 : 九州大学大学院農学研究院紀要. 58 (1)，pp.219-223，2013-02. Faculty of Agriculture， Kyushu University

バージョン :

権利関係 : 


\title{
Analysis on Policies and Agricultural Transition: Challenges in Promoting Sustainable Agriculture in Northern Laos
}

\author{
Boundeth SOUTHAVILAY ${ }^{1}$, Teruaki NANSEKI ${ }^{2 *}$ \\ and Shigeyoshi TAKEUCHI ${ }^{2}$
}

\author{
Laboratory of Agricultural and Farm Management, Division of International Agricultural Resource Economics and \\ Business Administration, Department of Agricultural and Resource Economics, \\ Faculty of Agriculture, Kyushu University, Fukuoka 812-8581, Japan \\ (Received October 31, 2012 and accepted November 8, 2012)
}

\begin{abstract}
Since 2006s, Lao agriculture has been transforming from subsistence farming to commercial farming system. The main objectives of this study were to review and evaluate the impact of the $6^{\text {th }}$ National Socioeconomic Development Plan (NSDEP) 2006 to 2010 that influencing in transition of agricultural production in the northern Laos. The analysis was emphasized on the targets of MAF's responsibility that including Land and Forest Allocation, Shifting Cultivation Stabilization and Commodity Production policies.

In conclusion, the result of these policies have emerged the new characteristics of the new agricultural production system are included fixed rotation system; modern rice based farming; annual cash cropping in monocultures and industrial plantations. Those farming activities have been promoting soil degradation and nutrient loss and are unlikely to maintain the current high yields and those farm types in the form of unsustainable agriculture. Among policies have also emerged contradictions. The commercial crop production has certainly contradicted with the forest management policy and environmental issue due to the market/private sectors have only concerned on increasing the volume of products without considering about the impact on land degradation and forest covers. Most of commercial crop investors encouraged farmers to increase farm size by expanding the new farmland from forest land and even steeper lands. The main causes of policy contradiction as the result of provincial staff have limited capacity to manage and interpret the policies, poor participation from villagers, unclear in models and guidelines. Moreover, farmers were often left with little room to negotiate and top-down decision process was common across in rubber and commercial crop production.
\end{abstract}

Key words: Laos, Agriculture, Policies, Transition

\section{INTRODUCTION}

In Laos, agriculture and forest-based activities are still providing the main livelihood sources for more than $90 \%$ of the upland households (MAF, 2010). The structure transition from subsistence to commercial crops, integration of markets and development of the rural non-farming business enterprise remain very limited. At the same time, agriculture contribution to overall gross domestic product (GDP) was decreased from 50\% in 2001 to $40 \%$ in 2006 (World Bank, 2008) and to 30\% in 2010 (Department of Statistic, MPI, 2012). Nonetheless the majority of the Lao population is remaining dependent on agricultural sectors.

The accelerating influence of regional market forces leads to increases in permanent intensive agriculture and changes in crop composition away from traditional swidden agriculture system (upland rice) to such cash crops as maize, sugar cane, soy bean, and Job's tears; and to

${ }^{1}$ Laboratory of Agricultural and Farm Management, Department of Agricultural and Resources Economics, Graduate school of Bioresource and Bioenvironmental Science, Kyushu University, 6-10-1 Hakozaki, Higashi-ku, Fukuoka, 812-8581, Japan; Department of Planning, Ministry of Agriculture and Forestry of Laos

2 Faculty of Agriculture, Kyushu University, 6-10-1 Hakozaki, Higashi-ku, Fukuoka, 812-8581, Japan

* Corresponding author: nanseki@agr.kyushu-u.ac.jp, Tel/fax: +81-92-642-2972 increasing numbers of livestock

The $6^{\text {th }}$ National Socio-Economic Development Plan (NSEDP: 2006-2010) is one of the most important policies of the Northern agricultural development. This plan was compiled by Government to implement the resolution of the $8^{\text {th }}$ Party Congress of March 2006. The aim of the plan on agricultural sector is to transform agriculture into a thriving sector based on innovative technologies and practices in high value-added production and processing, supplying to domestic and international markets.

In 2010, in the northern uplands was about 70-80\% of all farming systems were in a form of transition showing response to market dynamics and policies implementation (MAF, 2010). Therefore, the objectives of this study were to review and evaluate the impact of policies that influencing in transition of agricultural production system from subsistence based to market based.

\section{METHODOLOGY AND DATA}

The descriptive analysis was mainly used to explain and evaluate the impact of agricultural policies on land use and local livelihoods. The main data used in this study included the $6^{\text {th }}$ National Socio-economic Development Plan (NSDEP) and 4 goals of the Ministry of Agriculture and Forestry. This study was also integrated the field survey through the key informants interviewed and observed during cropping season in 2011, in 
Bokeo and Oudomxay provinces.

\section{Policies and Legal Frameworks}

Since 2004, government of Lao has established vision called Government's Statistic Vision 2020 for the development of agriculture, forestry, natural resource management and rural development. The vision is based on the holistic concept of long-term, sustainable development, including economic, social and ecological dimensions. To meet this vision, Ministry of Agriculture and Forestry (MAF) has formulated the 4 goals and 13 measures approved by $6^{\text {th }}$ NSEDP.

In order to achieve the strategies (transition from subsistence agriculture to market oriented) there were 3 elements as the main cornerstone of the government for upland development approach. 1) Land and Forest Allocation Program (LFAP); 2) Stabilization of Shifting Cultivation Program (SSCP); and 3) Four Goals of Agriculture and Forestry Sector.

\section{RESULTS AND DISCUSSIONS}

\section{Driving Transition to New Production Models and It Impacts}

The combination of upland policies and market forces has been driving the transition from traditional livelihood systems to new production models and the development for coping strategies of upland communities for livelihood security. The push and pull forces at times jointly reinforce and positively influence the transition but they contradict and restrict upland farmers' livelihood choices. According to GTZ (2007) revealed that disadvantage vil- lagers are also often accompanied by unintended side effects of policies.

It implies that the transition of traditional agricultural production system to commercial crops (market-based) cannot be applied for all rural farmers, especially for small scale farmers (stallholders) and shifting cultivators who have no experiences in large-scale mono-cropping. Those farmers may face with rice shortage, food insecurity because of those farmers have insufficient finance and techniques to invest in the commercial crops.

Figure 1 shows the combination of upland policies and regional market forces is driving a transition from subsistence farm type to commercial farm type models as well as changes in agricultural crop composition away from traditional upland rice toward a variety of cash crops and increasing numbers of livestock.

The impact of push factors has more intensive farming on sloping lands. These impacts are soil loss, soil fertility decline, increased weed, increased labor demand and increasing land conflicts (GTZ 2007). The main policy push (the $6^{\text {th }}$ NSEDP and 4 Goals), along with market pulls was the main cause of transition from subsistence farm type to commercial farm type (fixed farm rotation and mono-cropping system). The large scale of monoculture (maize production) has replaced upland rice and Non Timber Forest Product (NTFP) areas. Other weaknesses are declining yield and soil fertility, increase weeds and use of chemical fertilizers, pesticides, herbicides and insecticides (NAFRI, 2011).

However, the existing policies as stated in measure $6^{\text {th }}$ (producer organization) of four goals of MAF in the $6^{\text {th }}$ NSDEP that aimed to established production groups

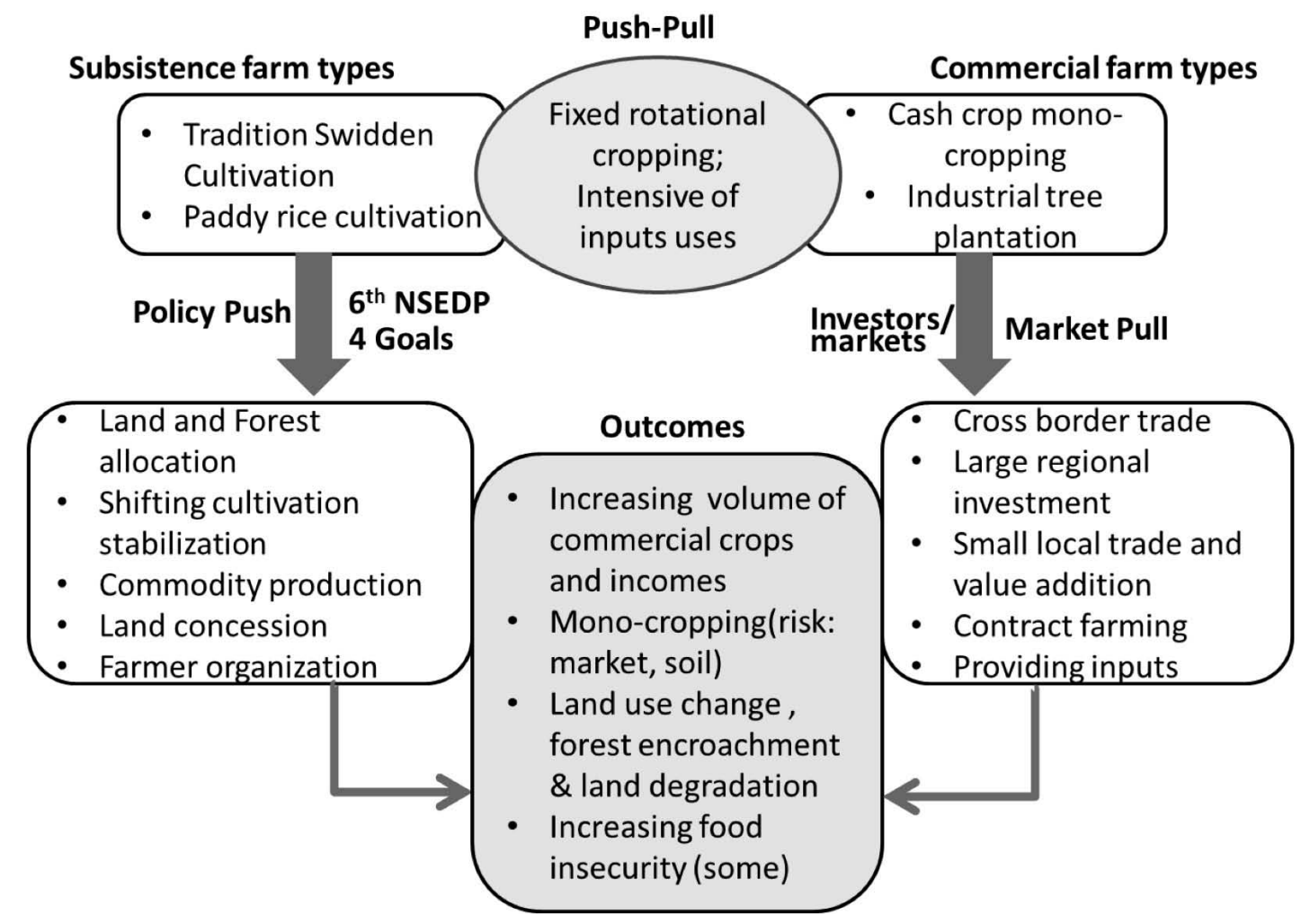

Fig. 1. Push and Pull Factors and Their Impacts on Upland Farming System. 
to facilitate marketing and strengthen bargaining powers of farmers and less to consider on land degradation and sustainable agriculture (Southavilay et al., 2011). At the same time, the policies have encouraged the private enterprises including those by foreign investors and traders from both domestic and neighboring countries to invest agri-business through the contract farming and land concession.

\section{Commercial Crop Production}

This policy includes three key factors mainly farmer organization, land concession and contract farming. The farmer organization is one of key factors to boost the transition of agriculture and it was established at the villagebased including farmer group and marketing groups are increasing throughout the country to facilitate production, marketing and contract farming. These groups offer potential to improve efficiencies of scale, local value added production and strengthen the bargaining position of farmers.

However, there were some of the productions groups were not well promoted and integrated by private sectors and government. For instance, the maize production group in Bokeo province had been facing with the financial and technical support from other parties (private sectors and local governments). This issue brought the maize farmers faced with inappropriate post-harvest techniques and low bargaining powers (Southavilay et al., 2010).

According to policy brief No.1 of Ministry of Agriculture and Forestry (2010) revealed that the land concessions have no accurate information on extent of land concessions; lack of provincial capacity to manage; poor participation from villagers; reduce or restrict village land use options; and lack of coordination between sectors and villagers.

The contract farming has unclear in models and guidelines, and then increasing land disputes and land grabbing; unclear contract and market arrangements, villagers are not well informed (SWGUP-MAF, 2008). Moreover, this policy has not met or completed its purposes that was to transform agriculture into a thriving sector based on innovative technologies and practices in high value-added production and processing, supplying to domestic and international markets.

\section{Land and Forest Allocation}

The purposes of this policy were to allocate forest and agricultural land for village use, contain and reduce shifting cultivation and stabilize agricultural practices by "arranging permanent occupations".

However, this policy has also brought many problems to villagers. For example, it has restricted family access to agricultural land and limited farming land areas (World Bank, 2008). According to the NSC-ABD (2007), found that this policy has affected on a reduction in the amount of upland agricultural land available to families for rotational cultivation. In addition, the policy has aimed to increase forest cover which has a potential to reduce the availability of village production areas if such policy is not participated and accompanied by villagers and village land use planning to meet village land requirement for livelihoods activities.

Those problems as the result of some issues as including land suitability maps and soil surveys are inadequate; land use planning are not included socio-economic factors; duplication of land zoning (unclear land use types and its boundary); the land use maps and land zoning maps in the village had not regarded land concession areas. Therefore, after implementing concession has resulted in land conflicts (SWGUP-MAP, 2008).

\section{Shifting Cultivation Stabilization}

The purpose of this policy the upland rice would be replaced with cash crops (commercial crops) and providing permanent occupations. However, without consideration of how this would be achieved. After this policy has been implemented, other options of agriculture production and permanent occupations strategy were not well or inappropriate provided to villagers (World Bank, 2008). Therefore, the problems of soil erosion and loss of productivity from inappropriate cultivation techniques of mono-cropping practices such as maize production in the Northern provinces are occurred (NAFRI, 2008 and Southavilay et al., 2011).

\section{Inappropriate of Agricultural Investment in Northern Laos}

Agricultural investors mainly operate through the $2+3$ and $1+4$ contract farming models in the northern uplands (LEAP, 2007). In this model farmers retain their land and use their own labor while investors are responsible for provide capital, techniques, and markets. For annual crops, this implies that farmers plant and investors/traders collect. For perennial crop such as rubber, $2+3$ is often associated with profit or product sharing schemes between farmers and investors (with farmers claiming a typical 70\%).

Based on field survey, we found that in the $1+4$ model, farmers obtained a worse share by contributing only land. Investors are responsible for the other inputs. If farmers work for the investors in this model, they receive wage compensation. In rubber investments, it is widely known that many $2+3$ contracts dissolve into the 1+4 model in implementation because farmers lack alternative income sources during the pre-tapping years. This was very hard for farmers to step out from the poverty hole.

Another form of investment was land concession for rubber plantation. It means that $100 \%$ of the firm will be run by investors. If farmers work for the investors, they will receive wage compensation. This model was seems like bring a lot of problems to local people in term of land conflicted, limited of right to access the area for NTFP collection. The problems as the result of almost of the land concession areas were located near the villages, overlapped farmland and covered common forests or former fallow of upland rice. Those areas have provided plentiful of NTFPs for daily household's consumption. 


\section{Top-down Decision-making, Hindering Direct Interactions between Investors and Farmers}

The government's extensive involvement in agricultural investment decisions hinders direct interactions between the private sector and the farmers, where the demands and interests of both sides can be communicated and negotiated openly. For example, Foreign Development Investment (FDI) decisions, in agriculture or otherwise is often made at a higher level (provincial and central) without thorough assessment of local situations.

Investment contracts with higher authorities then become instruments for negotiation with local authorities and farmers. Farmers are left with little room to negotiate. The top-down decision process is common across rubber, maize, and tea.

When government plays an interceding role between the private sector and farmers, the two sides often do not demonstrate a consistent understanding of contractual arrangements or mutual trust, creating possibilities for later disputes. Where the needs of investors/traders and farmers are sometimes mismatched. A rubber investor could well be assigned to a village where farmers have no desire to plant the crop, or where the farmers possess enough funds for planting already.

\section{Policies Contradiction and Challenging Agriculture in Northern Laos}

Based on the policies implemented, we could observe that some of them have overlapped and contradicted. For instance, decreasing of an access to land and natural resources of farmers was the result of land forest allocation program. On the other hand, the shifting cultivation stabilization policy has resulted in reduced of long term quality of crop land and NTFPs.

Another example, the policy of food security, the government has set a goal for farmers across the country to increase from 2.3 million tons of rice on 736,000 ha to produce around 3.8 million tons of rice on 860,000 ha of cultivation land for the 2012-2013 fiscal years (Vientiane Times Newspaper, $17^{\text {th }}$ July 2012). This means that about 124,000 ha of land will be required for rice production. This target will affect the reduction of other land use types, especially forest land and commercial crop areas.

Other examples of contradiction were between land concession and commercial crop production. According to the field survey was conducted during cropping season in 2010-2011. Maize was typical commercial crop to boost income of local people in Bokeo province. However, based on data survey also found that currently the figure of maize products has been declined about 50\% lower than its peak of 2008 (170,000 tons) when the prices were booming (Southavilay et al., 2011). Nowadays, two drying factories (silos) had closed down. The Silo which could process 300 tons of maize/day and was closely located near the new Mekong Bridge between Laos and Thailand, has been rented out to a Chinese company, who reputedly plan to build a trunk showroom.

The causes of decreasing of maize production there appear to be several reasons:
(1) Since GoL has fully opened for Chinese investors come to this region (north) for rubber plantations and cash crop productions. The price of land, labor and capital investment had significantly increased threefold, while the maize price is not much higher. For example in 2005 the labor cost was $1.8 \mathrm{US} \$$ /day, while it is now $6 \mathrm{US} \$ /$ day. Fertilizer cost was also much higher at least twofold.

(2) In the 2010s, we found that there were many maize farmlands have been rented out to Chinese companies for bananas, pumpkins and watermelons cultivations. Based on field survey found that the renting price was around $650 \mathrm{US} \$ /$ ha/year. And some of maize farmers could also work in those farms and plantations as labors, and neglecting their own traditional crops such as maize and peanuts.

(3) The current high price of rice has meant (700 US\$/ha) that many maize farmers had turned back to grow rice on their maize field and even some of them turn to cutting down forest for upland rice 'destroying forest' because input costs are lower than maize production as fertilizers are not needed for upland rice. According to the PAFO of Bokeo province (2011) reported that during last 10 years from 2001 to 2010 the forest cover of the Houay Xai district was decreased $70 \%$, in contrast of increasing the agricultural land that included upland and lowland rice.

(4) Another reason, during harvest season of 2010 Thai authorities had announced that Thailand was not accepting any maize from Laos until Mach in the year after (2011) and that maize farmers and maize business men had to store it until then. Based on this situation, Thai traders had dumping down price of Lao maize (for informal traded over Mekong River).

This finding found that there was contradiction among government policies. It was risky and high potentially more closely of maize production in the province. This may raise interesting questions to Agricultural Investment Plan 2011-2015 of Ministry of Agriculture and Forestry, which purposed to produce maize up to 1 million tones and Beans 95,000 tones in next five years.

\section{CONCLUSIONS AND POLICY RECOMMENDATIONS}

\section{Major Conclusions}

This analysis has provided background information on transition of subsistence farming system to commercial crop (market-oriented) in the northern Laos. The main factors behind the transition were discussed by focusing on the push-pull factors, inappropriate agricultural investment, top-down policies implementation and contradiction among policies itself.

The main data used in this study was the agriculture policies that influencing on transition. The main policies were reviewed includes the $6^{\text {th }}$ NSDEP 2006- 2010 and Strategy for Agricultural Development 2011-2020. This study was also integrated the field survey through the key informant interviewed and observed during cropping season in 2011, in Bokeo and Oudomxay provinces. The descriptive analysis was used to evaluate and assess the 
impact and output of the policies.

The analysis shows that the main policy behind the transition to new agricultural production system is the $6^{\text {th }}$ NSEDP with specific targets under MAF's responsibility that including Land and Forest Allocation, Shifting Cultivation Stabilization and Commodity Production policies. The result of these policies have emerged the new characteristics of the new agricultural production system are included fixed rotation system; modern rice based farming; annual cash cropping in monocultures and industrial plantations.

However, there was the contradiction among policies of the transition. For instance, the result of LFAP and commodity production policies which in the form of land concession have resulted in land access loss and led to create food insecurity for the poor people and who have limited of farming land. On the other hand, commercial crop production has certainly contradicted with the forest management policy due to the commercial crop was driven by the market to increase the farm size by expanding the farmland with exploitation of forest land and steeper lands for commercial crops (maize) and tree planting (rubber).

The main cause of policies contradiction as the result of has limited of provincial capacity to manage and interpret the policies, poor participation from villagers, unclear in models and guidelines. In addition, farmers were often left with little room to negotiate and top-down decision process was common across in rubber and maize production.

\section{Policy Recommendations}

(1) The transition to new agricultural production system provided benefit to only lowland based farmers who have experienced on large scale production and with improved infrastructure. It means that the new system is still early to apply to all rural farmers, especially for small scale farmers who have been relying on shifting cultivation and forest based for their livelihoods. In this case farmers may face with insufficient finance and techniques to invest in the commercial crops.

(2) The production group should be promoted and integrated work by private sectors and local including foreign investors and traders from both domestic and neighboring countries to invest agri-business through the production groups instead of directly contract and land concession. At the same time, the production group is a need to minimize some monopolies from private sectors.

(3) The conflict of land concession and contract farming should be addressed by the first the land use maps should be well interpreted to be understandable between investors and villagers. Second, government should not allow investors select and design their own concession land. Final the land law should be promulgated and restricted.

(4) The land and forest allocation policy should change from stabilization of shifting cultivation to provide land use zoning for resolving the conflict between forest land and commercial crops and rubber plantation.

(5) In order to avoid the contradictions among policies, it is necessary to interpret the policies into implementation version (easy to understand by local government and private sectors as well as villagers).

\section{REFERENCES}

Department of Statistic, MPI, 2012 available at http://www.nsc. gov.la/

GTZ 2007 Study on Land Conflicts and Conflict Resolution in Laos. Lao-German Land Policy Development Project Land Policy Study No. 9 under LLTP II. GTZ. Vientiane, Laos

LEAP 2007 Contract Farming in Laos: Case study and questions. NAFES, Vientiane, Laos

MAF (Ministry of Agriculture and Forestry) 2010 Strategy for Agricultural Development 2011 to 2020, Vientiane, Laos

MPI (Ministry of Planning and Investment) 2010 Draft $7^{\text {th }}$ National Socio-economic Development Plan (2011-2015). Working document for 2010 round table meeting, Vientiane Capital, (Laos) pp. 84-88

NAFRI 2008 NAFRI Strategies Plan for 2007-2012 and Research Agenda for 2007-2010, Vientiane, Laos

NSC-ADB (National Statistic Center -Asian Development Bank) 2007 Participatory Poverty Assessment 2006. ADB, Vientiane, Laos

PAFO (Provincial of Agriculture and Forestry Office) of Bokeo Province, 2011. Annual Agricultural Statistic Report, Bokeo Province, Laos

Ramron Iturrioz 2009 Agricultural Insurance. World Bank, pp. $1-28$

Southavilay, B., Nanseki, T., Hotta, K., 2010. Farm Organization in Maize Commodity Chain in Laos. Japanese Journal of Farm Management 49(2): 170-175

Southavilay, B., Nanseki, T., Takeuchi, S., 2011. Study of farmers' perception and socio-economic determinants on land degradation in northern Laos: a case study of maize production. European Journal of Social-Sciences 28(4): 502511

SWGUP-MAF 2008 Improving Upland Farming Systems for Poverty Alleviation. Policy Brief No. 1

SWGUP-MAF 2008 Rural Land Management and land Administration. Policy Brief No. 2

Vientiane Times Newspaper, $17^{\text {th }}$ July 2012 available at http:// www.vientianetimes.org.la/

World Bank 2008 Policy, Market, and Agriculture Transition in the Northern Uplands. World Bank, Washington 